\title{
Heidegger Nazism Ecocriticism
}

For the clarity we are aiming for is indeed complete clarity. But this simply means the philosophical problems should completely disappear.

(Wittgenstein, Philosophical Investigations 51)

In this essay I am hoping - perhaps over-optimistically - to make a problem that I have been wrestling with in ecocriticism for many years "completely disappear". The "history of the forgetting of Being" proposed by Martin Heidegger, an epochal grand narrative of the fall of Western philosophy from an originary revelation in pre-Socratic Greece, has captured the imaginations and invaded the language of ecophilosophers and ecocritics alike. In previous research, I have presented critical responses to Heidegger that have remained indebted to his language and philosophy. I now think that such immanent criticism fails adequately to confront his mistaken views on ontology, technology, history and poetry. Referring principally to the texts that have inspired ecophilosophers and critics, I will show that what is distinctive in Heidegger's work after Being and Time (1927) is wrong, and what is persuasive is not distinctive.'

The philosophical problem is compounded by a complex political one: Heidegger was an enthusiastic Nazi, and some senior Nazis were enthusiasts for ecological ideas. The Nazis' ideology promoted a mystical link between "Blood and Soil", while their legislative programme included progressive measures on nature conservation, protection of small farms and animal welfare. These uncomfortable truths have generated a certain anxiety amongst historians and ecocritics to disassociate modern environmentalism from Nazism, as well as enormous debate about the relationship between both of these and Heidegger's thought. I will argue here that we need not worry because ecocriticism can and should do without Heidegger - so his political affiliations are of merely antiquarian interest - and furthermore that Nazism was never seriously ecological. Insofar as I previously argued the opposite on both counts (Garrard 1998), this essay is something of a twofold mea culpa.

Heidegger's influence on ecophilosophy has been widely attested (Devall and Sessions 98; Foltz; Steiner 136). The foremost authority on Heidegger and ecology, Michael Zimmerman, summarizes his claim as follows:

Heidegger's critique of anthropocentric humanism, his call for humanity to learn to 'let beings be', his notion that humanity is involved in a 'play' or 'dance' with earth, sky and gods, his meditation on the possibility of an authentic mode of 'dwelling' on the earth, his complaint that industrial technology is laying waste to the earth, his emphasis on the local place and 'homeland', his claim that humanity should guard and preserve things, instead of dominating them - all these aspects of Heidegger's thought help support the claim that he is a major deep ecological theorist.

(Confrontation 242-3)

For ecocritics, Heidegger's importance is amplified thanks to his gnomic insistence that poetry has a special role to play in 'letting beings be', of which more below. 


\section{Heidegger's Question}

The underlying question to which Heidegger responded was: what is what is? Philosophers call it ontology, but Heidegger called it Seinsfrage, the question of Being, and his way of asking it is the basis of his entire claim to original and significant thought. Everything we encounter, each of the various "beings", has a range of attributes, or predicates: my dog has furriness, attentiveness, black-white-and-brown-ness, and perhaps some essential doggy-ness. Heidegger's supposed insight is that he and every other being has something like beingness as well. Bryn is a dog, he is an evolved canid, he is a certain configuration of bones, flesh and organs, and he is a domestic animal, but in addition he simply, mysteriously is (recourse to italics seems inevitable). But precisely because Being is so near - it is (there it is again) everything - it is far from everyday consideration. Moreover, just insofar as it discloses or reveals beings to us, Being veils itself. As George Steiner puts it:

Heidegger concentrates on the total thereness of ... particular existentials. They fill him with wonder. He stands soul- and spirit-deep in immanence, in that which is, and in the utter strangeness and wonder of his own 'isness' within it.

For Heidegger, philosophy had lost sight of the radical puzzle of "Being", the astonishment of "is" itself, very early on. Apart from himself, the pre-Socratic philosophers such as Parmenides and Heraclitus were, he thought, the last fully to register such awe at the immanence of Being (i.e. its inherence in beings themselves). The rest of the history of philosophy, he claimed, saw a succession of doomed attempts to ground Being in some other, more reliable, transcendental order. Plato argued for the suprasensible realm of eidos ("forms" or "looks"), while Descartes grounded the Being of beings solely in the relationship of rational subject, or ego, and object, thereby ensuring that things might thereafter appear to us (as sovereign subjects) as dependent and potentially manipulable. Heidegger saw the descent from Heraclitus to Husserl as a progressive "forgetting of Being", and his own project as its valiant, epochal commemoration.

Beings of course exist without human consciousness, but in order that they might attain to "Being", in the sense of showing up, disclosure, illumination or presence, a "space" must exist. Heidegger names this space, roughly equating to human consciousness, Lichtung, which means "forest clearing" but also has the sense of a space in which things are lit up, as Steiner suggests above. Language, which Heidegger assumes to be categorically different to all other forms of natural communication, opens up a Lichtung, founding human being as such. As Heideggerean ecocritic Robert Pogue Harrison puts it, the advent of language or logos in human history disclosed "a horizon of sense. The world suddenly became meaningful. It became phenomenal. It became, precisely, a world - and no longer a mere habitat" (5). Since neither Being nor "man" is fully autonomous, but rather each has a need, liking or attunement to the other, Heidegger's account of the opening of language, its ek-stasis or standing-outside of nature confronts the anthropocentrism of Cartesian philosophy. Language discloses a "world" of meaningful Being from an "earth" of mere extant beings, yet there could be no Being without beings.

Not only do the forest clearing and the things that "show up" there have a mutual need of each other, but Heidegger suggests that there might be better and worse ways 
for things to show up. Thus the free "shining forth" of Being, its unhindered "letting be," in front of the astonished pre-Socratic philosophers ultimately descends to the "challenging forth," or Ge-stell (usually translated as "enframing", but with a sense of a gimmick or a constructed façade) of the technological dispensation of Being, in which beings show up as mere resources of instrumental reason. The latter Heidegger characterises using the forestry term Bestand, or "standing timber". Enframing transforms the mysterious Wald or forest into lumber awaiting processing, while the hydroelectric dam made the "essence" of even the mighty Rhine dependent on the needs of technological man:

The hydroelectric plant is not built into the Rhine River as was the old wooden bridge that joined bank with bank for hundreds of years. Rather, the river is dammed up into the power plant. What the river is now, namely a water-power supplier, derives from the essence of the power plant.

(Heidegger, Basic 321)

Heidegger's alleged importance for ecocriticism lies in the combination of this critique of instrumental reason and technological modernity with a distinctive valorisation of poetry. Not only can listening to language, especially the ancient meanings of words, enable us to hear the call of Being - indeed Heidegger often uses etymological derivations as part of his arguments - but if language is the revelation of Being, poetry is potentially the revelation of that revelation, a disclosure that lets presencing itself presence. Hence Heidegger's writings include at least as many intense meditations on German poetry as they do philosophical engagements.

I intend to make Heidegger disappear by arguing that there is no question of Being, and that, even if there were, he would have no grounds for arguing that it had been progressively forgotten. His critique of instrumental rationality has been more clearly and cogently expressed by other writers, and his "confrontation with modernity" is, apart from its vacuous rhetoric of "Being," indistinguishable from contemporary German postromantic arguments for Heimatschutz (or homeland protection). Once the mood music of "saving the earth" is set aside, we can see that Heidegger's "question of Being" is actually so contemptuous of mere beings, and so suspicious of science as a mode of enframing, that ecological crisis could not but fall into the realm of the "inessential", beneath the notice of the philosopher's supposedly Wesentliches denken "essential thought," or "thought of essence." But first we must deal with the Nazi connection.

\section{Heidegger, Nazism and Ecology}

There is no gainsaying Heidegger's commitment to Nazism. Despite his post-war lies, it now known that he was a National Socialist Party member, card number 312589, Gau Baden, from May 1st 1933 until its dissolution in 1945. His enthusiasm got him the Rectorship of Freiburg University between April 1933 and February 1934, during which time he began to implement both the new racial policies and the "coordination" of the institution with the NSDAP "leadership principle" and its institutional structures. His speeches and actions during this period show his support for the revitalisation of the German people by means of racial legislation, as well as the territorial ambitions of the new regime. In addition, he hoped to lead the Führer to fulfil what he saw as the special German destiny of overcoming western metaphysics. The combination of sickening 
political servility with breathtaking philosophical arrogance is unedifying, but, as Hans Sluga's study has shown, hardly unique: philosophers from many traditions became Nazi supporters, and competed for a place at the heart of a movement that had neither an ideological centre nor a pressing need for academic philosophers to articulate it. Heidegger stands out because, philosophically, "All those others have faded away" (173).

Long after it became evident that Hitler was not looking for spiritual leadership, Heidegger continued to contrast what he saw as the potential "inner truth and greatness" of Nazism with its debased actuality. Having hoped that Nazism would overcome technological enframing, he eventually came to see its demeaning, "inessential" biological racism as another example of it.i Thomas Rohkrämer sees this change as pivotal, claiming that, while there are continuities in his thought, "Heidegger's involvement with Nazism and his thoughts on environmentalism belong to different phases of his work" (194). However, he never gave the least indication of having changed the view he developed in the 1930s that "saving the Earth" involved overcoming western metaphysics, and that the German language and people alone had that destiny and burden. And while he never expressly identified himself as the spiritual leader who could hear the "call of Being" after 1934, he never nominated any other candidates either.

One of the aspects of Nazism that attracted Heidegger in the beginning was the promise of a "third way" between Soviet Communism and the "Americanism" of unrestrained capitalism. What made Germans so appropriate for this historic task was their supposed "primordiality" - the myth that their language, race and territory had been maintained uncorrupted since the before the Roman Empire. The phrase that epitomised this purity was 'Blut und Boden' ("blood and soil”), which has been glossed as follows by Anna Bramwell:

What it implied most strongly to its supporters ... was the link between those who held and farmed the land and whose generations of sweat and tears had made the soil part of their being, and their being integral to the soil. It meant to them the unwritten history of Europe, a history unconnected with trade, the banditry of the aristocracy, and the infinite duplicity of monarchy and church.

In her enthusiasm for this aspect of Nazism, and her desire to exonerate its chief proponent Richard Walther Darré, Bramwell understates the point that the association was most often used to attract the peasant vote by attacking Jewish moneylenders who supposedly threatened German blood with racial contamination and German farms with repossession.

"Reich peasant leader" Darré, Minister of Agriculture and a powerful figure in the early years of Nazi rule, shared these seemingly "green" ideas of rootedness in nature with the Nazi's chief ideologue Alfred Rosenberg and the leader of the SS Heinrich Himmler. Darré and Himmler in particular were keen to promote organic agriculture and support small farmers while breaking the power, wealth and intensive monocultures of the great Junkers estates. Moreover, the Nazis were exceptionally popular with Naturschützer (members of nature preservation organisations), whose loyalty was rewarded with the 1935 Imperial Nature Protection Law, the first comprehensive framework for conservation anywhere in the world (Biehl and Staudenmeier, 
Ecofascism 17). Luc Ferry shows in The New Ecological Order that the 1935 law followed a 1933 animal protection law and another for control of hunting in 1934, forming "a very elaborate series of texts that is fully representative of a neoconservative interpretation of what would later be called 'deep ecology"' (92). Such evidence has led historians such as Simon Schama to argue that:

It is, of course, painful to acknowledge how ecologically conscientious the most barbaric regime in modern history actually was. Exterminating millions of lives was not at all incompatible with passionate protection for millions of trees.

One of the most striking examples of Nazi environmentalism was the sustained commitment of the team of architects assembled by Alwin Siefert to design the new Autobahn network, who tried, according to William Rollins, "not only to reconstruct an ecologically sound border alongside the Autobahn, but also to use the project as a stepping-stone to nationwide environmental reform" (494). Influenced both by William Morris and the theorist of "climax ecology" Frederick Clements, Siefert sought to reconcile beauty and utility, as well as ecology and economy, in his designs. He hoped that the highways would act as green corridors, reintroducing a diverse native flora back into Germany's intensively-farmed monocultural landscapes. If such arguments are accepted, it would seem that Nazism was a kind of "green party" both in terms of its leadership and its support amongst peasants and conservationists, and at the level of both ideology and practice - even in such unlikely contexts as road building.

Historians and critics who accept the notion of "Nazi ecology" nevertheless, like Schama, reject the notion that modern environmentalism should be tainted by this painful truth. Michael Zimmerman argues strongly that "while the fact that some National Socialists promoted a perverted 'religion of nature' must be taken into account today, that fact should not be allowed to discredit all contemporary attempts ... to recover a sacred dimension of the cosmos" ("Rethinking" 213). They are right to reject the notion of guilt by association, but wrong to accept too readily the notion of Nazi ecology itself. In fact Blut und Boden - or Blubo as it came to be contemptuously known - was a piece of passing electoral rhetoric for most Nazis, and a laughing-stock for many of the most senior, as well as for the population at large. The more Darré's vitriolic racism was complemented with support for organic farming, the more a leadership preoccupied with gearing up for war dismissed his ideas. Other neo-pagans such as Hess and Rosenberg were also sidelined.

The Imperial Nature Protection Law was impressive on paper, but had in fact been drawn up during the Weimar Republic before the Nazi revolution, and in any case relied on "nature advocates" who were usually volunteers. The requirement that they be consulted over development proposals was increasingly ignored as massive public works programmes, such as draining wetlands, got under way. Junker estates remained intact so as to maintain productivity and avoid alienating a powerful class, and the inexorable process of intensification of agriculture and loss of small farms continued. Neo-pagans and proto-environmentalists may have made up one of the early centres of power and ideology in the Nazi regime, but it was always a "polycentric" entity in which individual leaders and their organisations competed for influence and resources. The "green" element was quickly swept aside. 
As Raymond Dominick argues, "For the Fuehrer himself, Naturschutz and Heimatschutz ["Homeland Protection" - much like National Trust in the UK] were little more than quaint stage props in his unfolding drama of world domination" (520). The virulent, systematic racism and commitment to "race war" that distinguishes Nazism from other nationalist - even fascist - movements ensured that seemingly progressive measures such as animal welfare protection were used mainly to persecute Jews by banning ritual slaughter. When Hermann Göring unilaterally took over nature protection early in 1935 it was probably not in order to enhance its effectiveness but rather to increase his personal power, whilst also facilitating his favourite hobby: as Hitler himself observed, "First you protect the animals, then you shoot them dead" (quoted in Dominick 535). Göring's responsibility for the Five Year Plan for productivity was clearly a priority. While there seemed at first to be some points of ideological overlap between Nazism and proto-environmentalism, and individual conservationists did enthuse about the Nazi revolution out of opportunism or genuine conviction, there is no evidence that the regime was, in practice, remotely "ecologically conscientious."

Although the laws look impressive even today on paper, detailed analysis of the policies of the 1930s shows initial cooperation and enthusiasm quickly turning to disillusionment. In the case of the autobahn, a key exhibit of the "green Nazism" argument, Siefert's ecological objectives met resistance not only from economically minded planners, but also from locally based preservationists. As Thomas Lekan's study of Rhenish organisations shows, the plan to drive an Autobahn through the Siebengebirge nature protection region was actually promoted by Siefert against the advice of both the Rhenish provincial and the Imperial nature protection offices: local Naturschützer opposed the autobahn route on the grounds that it would disrupt an historic landscape of great significance in Rhenish tradition, whereas Siefert argued that the Siebengebirge was in fact merely a cultured landscape, that it "was 'unnatural' because it did not contain stands of native climax vegetation according to the emerging science of plant ecology" (397). In the event the war ensured the road was never built, but the incident indicates how culturally orientated local preservationists had to resist not only the demands of a centralising, militaristic state, but also "ecological" arguments designed to neutralise their opposition and ensure that drivers on Siefert's Autobahn could enjoy the delights of the Rhenish landscape as they travelled.

The conjunction of Blut und Boden in early Nazi ideology is certainly arresting, but one need only look at the later development of Nazi policy to see how the two sides of Blubo were really weighted in the minds of the regime's leaders: the ferocious adherence to the concept of race war helped cost Germany the war in the East by alienating Soviet subject peoples and later by diverting precious resources to the administration of the "Final Solution", whereas the supposed Germanic care for the land resulted in little more than a handful of organic herb gardens for convalescing SS officers. In short, whereas Heidegger despised the rhetoric of blood (albeit not morally) and understood his allegiance to the German soil in abstrusely philosophical terms, the Nazi regime was incomparably more obsessed with blood than soil. The guilty chain of association between Nazism, Heidegger and ecology is brittle at every link.

\section{Ecocriticism without Heidegger}


According to Wittgenstein, "philosophy is a battle against the bewitchment of our intelligence by means of language" (47). If so, Heidegger is the arch-sorcerer and enemy of philosophy, not its self-appointed destiny. As I argue later, he offers dodgy etymological derivations posing as the recovery of language's deepest resources in place of rational argument. In addition he proposes highly contentious readings of philosophical and poetic texts that are sometimes themselves fragmentary or apocryphal. Sometimes he gets it comically wrong: in "The Origin of the Work of Art", Heidegger claims to discern in Van Gogh's painting of a pair of peasant shoes the "toilsome tread of the worker" in its inarticulate responsiveness to "the silent call of the earth" (Basic 159). In fact, the shoes were those of the artist himself. As for Heidegger's controversial readings of German poetry, Veronique Foti's study concludes that he continually "essentializes"

Heidegger cannot countenance poetry as a tenuous writing against loss (as it shows itself in Holderlin and certainly in Trakl), nor as refractory to destinal constructs. Moreover, he cannot speak to the contemporary situation of poetry, to what both Adorno and Celan problematize as its very possibility and possible identity in the wake of the Shoah [Holocaust]. ${ }^{\text {iv }}$

Heidegger could only comprehend poets and philosophers in the light of their roles in his metaphysical drama, roles that he had assigned and effectively scripted in advance.

As numerous later commentators have pointed out, Heidegger seems not to have noticed that his "history of Being" suffers from a profound contradiction between nostalgia for a lost alertness to Being and a recognition (shared with much antifoundationalist philosophy) of the radical contingency of metaphysical discourses. Richard Rorty shows how Heidegger presents a convincing case that no historical understanding of Being, be it pre-Socratic, Platonic, Cartesian or Heideggerian, could be preferable to any other, since there is no extra-historical standpoint - no God's eye view, so to speak - from which such a judgment could be made (Essays): he "never tells us how we can be historical through-and-through and yet ahistorical enough to step outside our world-view and say something neutral about the 'structure' of all actual and possible world-views" (42). Heidegger frequently evinces a degree of admiration for a lost epoch of authentic openness to Being, and concomitant virulent contempt for contemporary technological society, that his own critique of ahistorical metaphysics ought to have ruled out. As Terry Eagleton observes, "Without some strong implicit normativity there could be no critique of the alienated world of prattle and mass opinion, not to mention science, democracy, liberalism and socialism; but for Heidegger's work to have true authority it must go beyond mere doxa [opinion] to describe things as they really are, draw its title to speak from the very nature of Being itself rather than sink into controvertible interpretations" (Ideology, 307). Which is why Heidegger's allegedly "ecological" demand that we "let beings be" is at once so rhetorically central to his philosophical ethos and so morally vacuous.

The most serious charge, however, is the claim that there is no question of Being. Philosophers such as Christopher Norris who are not hypnotized by Heidegger's sententious ramblings point out that Heidegger's supposedly primordial thought of "Being" is actually a straightforward philosophical mistake "deriving from an elementary muddle about the logical grammar of such words" (242). To "be" is not to have some 
mysterious self-manifesting quality over and above the other qualities we ascribe to a thing. What Heidegger would have us see as the awesome, humble disclosure of what "is" must instead be seen as merely a word with variable grammatical functions. To return to my dog, the existential claim that "Bryn is" might conceivably advert to some mysterious "Being", but "is" can also function as a mere copula connecting the subject "Bryn" and the predicate "furry". To which we might add identity claims such as "Bryn is my dog". As Richard Polt points out, "The copula does not seem to imply any existential claims: for instance, if I say, 'Unicorns are white', I certainly do not mean to imply that unicorns are, that is, exist" (27). So Heidegger's assumption that every banal predicative 'is' disguises an amazing, forgotten existential 'is' - is wrong. Wittgenstein is, as ever, the best antidote to bewitchment by the language of metaphysics:

When philosophers use a word - "knowledge", "being", "object", "l", "proposition", "name" - and try to grasp the essence of the thing, one must always ask oneself: is the word ever actually used in this way in the language-game which is its original home? - What we do is to bring words back from their metaphysical to their everyday use.

The truly distinctive aspect of Heidegger's philosophy, the history of the forgetting of Being and the Seinsfrage, is a contradiction inspired by a mistake.

The relatively valuable aspects of Heidegger's philosophy include his critique of technological enframing and talk of "saving the earth", but there is nothing distinctive about his contribution once the overarching question of Being is made to disappear. For example, the famous attack on the Rhine hydroelectric plant clearly echoes that of the founder of German Naturschutz movements, Ernst Rudorff, who campaigned unsuccessfully in the late 19th century to rescue the Rhine rapids at Laufenberg (Riechers 39). Heidegger's romantic conservatism, his attacks on both bolshevism and 'Americanism', and his critique of instrumental reason were shared by the prominent advocate of Naturschutz and Freiburg colleague, Professor of Zoology Konrad Guenther. Like Heidegger, Guenther idealised the German peasantry and became an enthusiastic Nazi supporter, adapting his nature protection ideas to the racialised biological framework of the new regime (Dominick 513, 526-7). Insofar as contemporary ecophilosophy finds uses for a critique of Enlightenment rationality, other writers such as Marxists Theodor Adorno and Max Horkheimer or - more recently - ecofeminist Val Plumwood have given more nuanced, demystified and rational accounts of it.

Even if there were an epoch of technological enframing, Heidegger's interest would lie in analyzing its supposed "essence", rather than understanding the development and differentiation of technology in terms of its ecological impact. From the perspective of the history of Being, renewable forms of energy generation are just the same as non-renewable and polluting ones, wind farms no better than coal-fired steam turbines. Indeed the science of ecology, which alerts us to environmental problems and proposes means of mitigating them, is also "in essence" technological.

The most striking example of how Heidegger demotes the plight of beings (human or not) is to be found in the original lecture "The Enframing" that was doctored to yield the famous essay "The Question Concerning Technology", published in 1949. Heidegger's original claim was that, in terms of the epoch of enframing: 
Agriculture is now a motorized food industry: in its essence it is the same thing as the manufacture of corpses in gas chambers and extermination camps, the same thing as blockades and the reduction of an area to hunger, the same as the manufacture of hydrogen bombs.

(Heidegger, "Enframing" 217) This analogy, suppressed in the published essay, is one of the very few instances in which Heidegger mentions the Holocaust. He relativizes Nazi crimes by equating them with the Allied blockade of Germany as well as the bombing of Hiroshima and Nagasaki, but also argues that the enframing of fields of wheat is "in essence the same" as the reduction of the racial enemies of Nazism to "standing reserve", on call for annihilation. Troubling as this analogy is, for animal rights activists, there is a morally valid analogy between the mass slaughter of animals in factory systems and that of racial "subhumans".

However, the real point is not that Heidegger has apparently elevated intensive agriculture to the moral seriousness of genocide, but rather that - in terms of "essential thinking" - both are equally unimportant. ${ }^{\vee}$ Heidegger deployed an apparently familiar rhetoric of "saving the earth", but what he meant by it was something so "essential", so metaphysical, it is clear that even global warming would be "the same" as pea-farming, "the same" as damming the Rhine, "the same" as Auschwitz. To "save the earth" is to redeem Being from Western metaphysics, not to find solutions to empirical problems. vi The essence of Heidegger's argument is nonsense, and what is not is freely available elsewhere without the surplus metaphysical baggage.

So what would ecocritism look like without Heidegger? Measured quantitatively, the loss is not likely to be great since rather little is directly reliant on his ideas, and since the influence of Maurice Merleau-Ponty has come to predominate. However, two of the most important works in ecocriticism to date are, in different ways, Heideggerian: Robert Pogue Harrison's marvellous Forests: The Shadow of Civilisation (1992) and Jonathan Bate's seminal The Song of the Earth (2000). In the latter, Heidegger's presence is overt and pivotal, but also counter-balanced in the book's dialectical structure, whereas in the former it is pervasive yet curiously subterranean. The capacity of each argument to survive the disappearance of Heidegger is correspondingly different.

Forests depends on Heidegger on multiple levels. Indeed, even as Harrison argues that forests "shadow" civilisation, it would appear that Heidegger shadows Forests, for the philosopher's name appears on nearly half of the fourteen pages of endnotes, but not once in the main body of the text. For example, one of the most idiosyncratic and problematic aspects of Heidegger's philosophico-poetical "method" is his practice of using etymology to excavate centuries of linguistic accretion to the supposedly most "essential" meanings of words, which always turn out to have decidedly Heideggerian implications. In "Building Dwelling Thinking", Heidegger finds that bauen, to build, has a "proper" meaning in Old High German of "to dwell". Moreover, the German "ich bin", or "I am", is also allegedly rooted in the same buan, thus to be is to dwell. Thus the problem of dwelling in post-war Germany is not a matter of rebuilding shattered cities, but attending to Being in a Heideggerian sense. (One might well ask what Heidegger's audience of architects and city planners made of this claim.) Even favourably-disposed critics have described his etymologies as "fanciful" 
(Polt 133) and "frequently arbitrary" (Steiner 243); Norris calls them "mystified pseudophilological verbiage." (xxi)

Harrison's etymologies are similarly radically selective of the meanings relevant to the argument from a wide array of archaic senses of words. When analysing Aristotle's argument for the priority of form over matter, morphe over hyle, he notes the latter "does not originally mean matter, it means forest" (29, my emphasis). And when the Romans translated hyle, they used materia, which - as well as meaning "matter" or "substance" - "means wood - the usable wood of a tree as opposed to its bark, fruit, sap, etc" (29). These supposedly more primordial meanings reveal the forest as the originary matrix, the fundamental matter, from which the ancient civilisations are formed, yet the choice of the moment of linguistic "origin", and of the "essential" meaning from the range of possibilities that etymological reconstruction provides, are not found, or "heard" and "heeded" as Heidegger preferred to put it, but made. It is not so much an etymo-logic as an etymo-poetic process of conjuring from the murk of ancient meanings a spirit that reveals exactly what the magician would have it reveal. It is a fascinating process that attributes to language an intriguingly mystical but strictly false autonomy as "the master of man" as well as the "house of Being" (Basic 348, Poetry 132). Heidegger even claims that it is not he who plays with words, but rather "language plays with our speech - it likes to let our speech drift away into the more obvious meanings of words. It is as though man had to make an effort to live properly with language." (388) What could account for this bizarre combination of mastery and misdirection is never explained.

Moreover, they share not only a relationship to language in general, but a correspondence of terms in particular. Heidegger's language in his late philosophy is saturated with the terminology of forestry, no doubt in part to reinforce the philosopher's own self-conception as a kind of Black Forest philosopher-peasant, equally at home puffing on a pipe with a rustic neighbour or deconstructing Kant. ${ }^{\text {vii }}$ As explained above, terms such as Lichtung and Bestand become philosophical concepts that Harrison, in a neat application of a kind of hermeneutic circle, then reapplies to forestry. Having read the forest as a scene of tragic confrontation and metamorphosis in antiquity, and comic inversion and reconciliation in mediaeval and Renaissance culture, Harrison notes the reduction of the forest to mere standing timber in the eighteenth century:

For this sort of enlightened humanism ... there can be no question of the forest as a consecrated place of oracular disclosures; as a place of strange or monstrous or enchanting epiphanies; as the imaginary site of lyric nostalgias and erotic errancy; as a natural sanctuary where wild animals may dwell in security far from the havoc of humanity going about the business of looking after its 'interests'. There can be only the claims of human mastery and possession of nature - the reduction of the forests to utility.

Thus the notion of Bestand, or "standing reserve", which Heidegger posits as "an inclusive rubric" that "designates nothing less than the way in which everything presences that is wrought upon by the revealing that challenges" (i.e. Ge-stell or enframing, Basic 322), is given a local habitation and a name, and even incarnation in the "Forstgeometer, or forest geometer, who measured the borders of forests, drew up maps and calculated the essential data." (Forests 122) Heidegger's metaphorical appropriation of forestry terms along his path of thinking (Feldweg, or meandering field- 
path) makes possible Harrison's appropriation of his appropriation, leading not so much to a re-literalisation of such language, but to a role for Lichtung, Bestand and so on as metaphors for metaphor. In the forest, in the shadow of civilisation, Harrison finds evidence for the character of human being as such, but of course (to paraphrase Byron's criticism of Wordsworth) he can only find such sermons in stones and tongues in trees because Heidegger had hidden them there earlier.

Harrison's overt structure is indebted to the eighteenth century Italian Giambattista Vico, whose "creative archaeology of the metaphorical origins of human thought" (8) provides the basis of the compelling movement in the book from prehistoric unity to Enlightenment alienation, Romantic nostalgia and modern irony. Its real indebtedness, however, is to Heidegger's history of the forgetting of Being, albeit at the subterranean level as I have indicated. Thus Forests takes its place amongst numerous ecophilosophical versions of the ancient Greek myth of decline from a Golden Age of originary plenitude (Heidegger's pre-socratic self-disclosure of things, Harrison's culture of the goddess) to a contemporary Age of Iron. From the history of the forgetting of Being in Heidegger's The End of Philosophy through Carolyn Merchant's The Death of Nature and Max Oelschlaeger's The Idea of Wilderness to Forests, critics have found the basis of our current environmental crisis in the historical development of ideas about nature. The result is a narrative of decline that is more or less linear and more or less inevitable. As Richard Rorty puts it, Heidegger's account is a "downward escalator" from Plato to Nietzsche "and, worse yet, [American pragmatist] Dewey" (28).

Such narratives of decline not only neglect the importance of contingency in historical change - luck, in other words - but also place massively excessive emphasis on ideas as determining factors (the ideas of philosophers in particular). Considerations of space prevent detailed discussion of this point here, but perhaps it is worth urging that ecocritics base their sense of how we arrived in our current predicament, and the limitations on how we might escape it, on properly ecological grounds. The philosophical implications of Christianity or Enlightenment rationality or Renaissance patriarchy might come to seem largely incidental, or else as discourses that emerged to legitimize developments that occurred mainly for other reasons. Clive Ponting's $A$ Green History of the World portrays environmental destruction as a concomitant of human population growth and technological change around the world and throughout history, assigning a rather minor role to 'Ways of Thought', while Alfred Crosby's Ecological Imperialism claims that the ferociously destructive character of European imperialism was due more to strictly ecological accidents and necessities than to unusually ruthless ethnocentrism. John Gray's polemical attack on humanism, Straw Dogs, puts the point with characteristically exaggerated assertiveness:

The destruction of the natural world is not the result of global capitalism, industrialisation, 'Western civilisation' or any flaw in human institutions. It is a consequence of the evolutionary success of an exceptionally rapacious primate. Throughout all of history and prehistory, human advance has coincided with ecological devastation.

Gray's claim is absurdly overstated, but ecocritics should be more skeptical of "histories", such as those offered by Heidegger and Harrison, which are seen as "ecological" despite making no mention of the impact of climate, biogeography and 
species-typical characteristics of Homo sapiens. Culture and ideas need not be reduced to a mere reflex or epiphenomenon of ecological change, but equally ought not be represented as a dominant and autonomous order.

Jonathan Bate's indebtedness to Heidegger in The Song of the Earth is overt and anxious. For example, the Heideggerian notion of the reciprocity of beings and the Lichtung of human consciousness is reflected in the claim that "things need us so they can be named" (265). Unlike Harrison, who provides a largely chronological account of successive epochs of Being, Bate works from prose to poetry to philosophy, devoting most attention to Romantic political theory and poetry, but also putting forward subtle and persuasive readings of a post-Romantic Modernist tradition that includes Elizabeth Bishop, Wallace Stevens and Les Murray. The underlying critical project of the book is the adumbration of "a longing for belonging that is the essence of ecopoiesis", Bate's Heideggerian term for his conception of ecocriticism (212). Its methodology throughout is chiasmic ix: Bate explores Wordsworth's love of place, his "tender protectiveness" (212) towards the land, but counterbalances such a centripetal devotion to the local with Byron's cosmopolitan, centrifugal satire Don Juan; he quotes Adorno's defence of natural beauty approvingly, but also Oscar Wilde's view that "Nature is so uncomfortable", imperfect and unfinished (120). The method extends into the final chapter, a manifesto for Heideggerian ecopoiesis in which the philosopher is matched with a poetic admirer, Paul Celan, whose poem "Todtnauberg" implicitly criticizes Heidegger's silence about Nazi crimes.

Kate Rigby's reconsideration of Bate's project exonerates Heidegger's philosophy from deep complicity with Nazi notions of blood and soil, but argues that the view of language he has beqeathed to The Song of the Earth shows evidence of "persistent human racism" thanks to the privileged role it assigns to human consciousness as the clearing in which earth becomes world (433). Against such a strongly anthropocentric view, she claims that "we need poets not so much to draw things into Being through their song, but rather to draw us forth into the polyphonic song of our nonhuman earth others" (434). Her insightful analyses of contemporary ecopoets give some ideas as to how such a song might begin to be sung, but, as she acknowledges, the nonhuman "voices" remain absent, and can only be made "present" by acts of deliberate appropriation by human artists. The Heideggerian view of language as categorically different from other animals' forms of communication, which he shares with most of the humanistic tradition, remains resilient and intransigent.

However she goes on to suggest that the poet can "speak of things in a way that allows them their own being" by adverting to the excess of earth over the world we make of it in a work of art: "in the poetic work, earth is preserved precisely in its unsayability" (436). Against Bate's argument that the poem saves the earth from technological enframing by imagining it otherwise, Rigby points out that even poetic language may "en-frame". However, the poem draws attention to its own "status as text and hence as a mode of enframing. In this sense, the literary text saves the earth by disclosing the nonequation of word and thing, poem and place" (437). Her position has clear affinities with the Russian Formalist notion that poetry "lays bare its devices", which was later taken up by Marxists such as Bertolt Brecht and Theodor Adorno who defended Modernist experimentation from the proponents of realism, principally Georg Lukacs. ${ }^{\mathrm{x}}$ The Song of the Earth seeks a middle path: Bate reads Keats's "To Autumn" 
alongside evidence of changes in the weather, implying a mimetic relationship of world and text, but more often poems are "imaginary ecosystems" in their own right. Rigby's argument for a decisive, principled refusal of "enframing" mimesis would seem to require the development of ecocritical "alienation effects" in modern literature so that it might lift up a song of the earth, fall short of articulating a non-human nature greater than we can say, but then seize on such necessary and celebrated failure as art's distinctive victory over - as well as instance of - anthropocentrism. Rick Bass's novel Fiber (1998) is perhaps the nearest thing in modern literature to Rigby's demand that, since "there is, in the end, no substitute for our own embodied involvement with the more-than-human natural world" (440), we eventually stop reading and theorizing and go outside. However, the exquisite combination of Heideggerian astonishment at Being, postmodern ironic self-consciousness, avant-garde poetics and physical engagement called for in Rigby's work makes it unlikely many more examples could be found.

That is one way of overcoming Heidegger, but it functions more as a correction than an elimination, as does Bate's self-critical response to Heidegger's question (derived in turn from Hölderlin): "What Are Poets For?" They can, he claims, save the earth by "reawakening the momentary wonder of unconcealment" (258) and thereby teach us to dwell in the light, or clearing, of such a revelation. However, Bate is also acutely aware of the threat hiding within the promise of "dwelling", namely the "disturbing connections between ecologism and extreme right-wing politics" (267) that reach such a seemingly decisive nadir in the case of Heidegger. Thus Bate presents a vision of ecocriticism that is decidedly utopian, saying that

works of art can themselves be imaginary states of nature, imaginary ideal ecosystems, and by reading them, by inhabiting them, we can start to imagine what it might be like to live differently on the earth.

The case of Heidegger is specifically cited in support of Bate's key argument: "The dilemma of Green reading is that it must, yet it cannot, separate ecopoetics from ecopolitics" (266). The utopian impulse is supposed to stay emphatically in the imagination, and just in case one supposes that Green utopias such as William Morris's News from Nowhere or Ernest Callenbach's Ecotopia are the sorts of "imaginary ideal ecosystems" Bate has in mind, he also condemns "Histories, theories, political systems" as "all enframings" (268). Seldom has Heidegger's philosophy received a more Romantic and humanistic inflection.

In fact, there seem to be three different arguments behind the painfully necessary (but impossible) divorce of poetry and politics: that "it would be quixotic to suppose that a work of literary criticism might be an appropriate place in which to spell out a practical programme for better environmental management" (266); that Heidegger's case shows that ecopolitics might drag ecopoetics down some dangerous paths; and that ecopolitics are in any case so diverse that they might mean anything - and therefore mandate nothing - for ecopoetics. On the first point, it is true that ecocriticism broadly must, in general, "concern itself with consciousness" (266), but that has not prevented critics engaging with specific environmental issues in some detail, as in Barney Nelson's treatment of open range grazing in The Wild and the Domestic and Richard North's analysis of the reporting of oil tanker disasters in Life on a Modern Planet. Clearly ecocritical analysis of Modernist poetry is never going to be "political" in this sense 
however. The third argument is correct, but even as the political polyvalence of ecologism undermines the critic's sense of having a secure political ground, it provides her with an additional object of criticism. The second argument, which motivates much of the discussion of Heidegger in Bate's last chapter, is mistaken because, as I have argued above, the seeming kinship of Nazism and ecologism is largely superficial. Ecocriticism may not have very much to learn from ecopolitics, but it does not have much to be afraid of either.

Making Heidegger disappear from The Song of the Earth would leave the valuable chiasmic method of mutual critique, the broadly Romantic humanist approach and the detailed readings of canonical texts intact, whilst also lessening the fatal antagonism of poetry and politics. Sadly Harrison's subterranean debt to Heidegger is so profound Forests simply cannot survive his absence, whereas Bate's overt and troubled engagement leaves Heidegger exposed to elimination with less difficulty. Indeed Bate supplies several other critical bases in the book, including Frankfurt School Marxism and Romanticism, for the defence of imagination against instrumentalizing rationality. I am all too aware that it is highly unlikely that either Heidegger or the chimera of "Green Nazism" can be made to disappear quite so cleanly and decisively, but the "complete clarity" of which Wittgenstein writes is nevertheless a worthy goal ${ }^{\mathrm{xi}}$. Finally, if my argument can spare even a single ecocritic the disproportionate and unrewarding effort of reading Heidegger, I will consider it vindicated.

\section{Works Cited}

Bass, Rick. Fiber. London: University of Georgia Press, 1998.

Bate, Jonathan. Romantic Ecology: Wordsworth and the Environmental Tradition.

London: Routledge, 1991.

Bate, Jonathan. The Song of the Earth. London: Picador, 2000.

Biehl, Janet and Staudenmeier, Peter. Ecofascism: Lessons from the German

Experience. Edinburgh: AK Press, 1995.

Bramwell, Anna. Blood and Soil: Walther Darré and Hitler's 'Green Party'. Bourne End,

Bucks.: Kensal Press, 1985.

Buell, Lawrence. The Environmental Imagination: Thoreau, Nature Writing and the

Formation of American Culture. London: Princeton University Press, 1995.

Devall, Bill and George Sessions, eds. Deep Ecology: Living as if Nature Mattered. Salt

Lake City: Gibbs Smith, 1985.

Dominick, Raymond. "The Nazis and the Nature Conservationists." The Historian, 49 (1997): 508-538.

Eagleton, Terry. The Ideology of the Aesthetic. Oxford: Blackwell 1990.

Ferry, Luc. The New Ecological Order. Trans. Carol Volk. London: University of Chicago Press.

Foltz, Bruce. Inhabiting the Earth: Heidegger, Environmental Ethics and the

Metaphysics of Nature. Atlantic Heights, NJ: Humanities Press1995.

Foti, Veronique. Heidegger and the Poets: Poesis / Sophia / Techne. Atlantic Heights, NJ: Humanities Press 1992.

Garrard, Greg. "Heidegger, Heaney and the Problem of Dwelling." In Writing the

Environment: Ecocriticism and Literature, Richard Kerridge and Neil Sammells, eds.

London: Zed Books, 1998. 167-81. 
Gray, John. Straw Dogs: Thoughts on Humans and Other Animals. London: Granta, 2002.

Harrison, Robert Pogue. Forests: Shadows of Civilisation. London: University of Chicago Press, 1992.

Heidegger, Martin. Poetry Language Thought. Albert Hofstadter, ed. and trans. New York: Harper and Row, 1971.

----- Basic Writings. David F. Krell, ed. and trans. Routledge: London 1993 2nd edn. ------ "The Enframing". In Alan Milchman and Alan Rosenberg, eds. Martin Heidegger and the Holocaust. Atlantic Heights, NJ: Humanities Press 1996.

Lekan, Thomas. "Regionalism and the Politics of Landscape Preservation in the Third Reich", Environmental History 4, 3 (1999): 384-404.

Levinas, Emmanuel. The Levinas Reader. Ed. Séan Hand. Oxford: Blackwell, 1989. Llewelyn, John. The Middle Voice of Ecological Conscience: A Chiasmic Reading of Responsibility in the Neighbourhood of Levinas, Heidegger and Others. London: Macmillan, 1991.

Norris, Christopher. What's Wrong with Postmodernism: Critical Theory and the Ends of Philosophy. London: Harvester, 1990.

Polt, Richard. Heidegger: An Introduction. London: UCL Press, 1999.

Riechers, Burkhardt. 'Nature Protection During National Socialism', Historical Social Research 21, 3 (1996): 40-7.

Rigby, Kate. "Earth, World, Text: On the (Im)possibility of Ecopoiesis". New Literary History 35 (2004): 427-42.

Rohkrämer, Thomas. "Martin Heidegger, National Socialism, and Environmentalism.' In How Green Were the Nazis?, Franz-Josef Brüggemeier, Mark Cioc and Thomas Zeller. Athens, OH: Ohio University Press, 2004. 171-99.

Rollins, William. "Whose Landscape? Technology, Fascism, and Environmentalism on the National Socialist Autobahn". Annals of the Association of American Geographers. 85, 3. (1995): 494-520.

Rorty, Richard. Essays on Heidegger and Others. Cambridge: Cambridge University Press, 1991.

Schama, Simon. Landscape and Memory. London: HarperCollins, 1995.

Sluga, Hans. Heidegger's Crisis: Philosophy and Politics in Nazi Germany. London: Harvard University Press, 1993.

Steiner, George. Heidegger. London: Fontana, 1992, $2^{\text {nd }}$ edn.

Wittgenstein, Ludwig. Philosophical Investigations. Oxford: Blackwell, 1953.

Zimmerman, Michael. Heidegger's Confrontation with Modernity. Indianapolis: Indiana University Press, 1990.

------ "Rethinking the Heidegger - Deep Ecology Relationship". Environmental Ethics. 15 (Fall 1993): 195-224.

\footnotetext{
${ }^{\mathrm{i}}$ It is unfortunate, and perhaps symptomatic, that Heidegger's early philosophy of temporality, everyday at-handness and mortality, which presents some intriguing ideas to a pragmatic ecocriticism, has been more or less wholly eclipsed by his later, far more involuted "homey murmurings", as Adorno called them. ii Metaphysical racism, on the other hand, is fundamental to Heidegger's "historial" project.

iii The typography is meant to indicate the notion of reductive characterization in terms of the question of Being (esse).
} 
iv Theodor Adorno wrote that "After Auschwitz one can no longer write poetry" (cited by Foti 74), although, as a reviewer informed me, he later retracted the claim.

"Heidegger's student Emmanuel Levinas argues that ethics, not ontology is "first philosophy", which appears to be a similar point to mine: "This is the question of the meaning of being: not the ontology of the understanding of that extraordinary verb, but the ethics of its justice." (Reader, 86) But whereas Levinas' mystification of the "face of the Other" purchases ethical torque at the cost of still-greater verbal obfuscation and effective moral vacuity, I prefer to draw upon the British empiricist and American pragmatist traditions.

${ }^{v i}$ Polt quotes an untranslated Heidegger text that claims that "devastation ... rules" even where comfort, well-being, harmony and human rights prevail, but where the mysterious call of Being is not heard (172). Likewise, an empirically sustainable society that ignored the Heideggerian Seinsfrage would still have failed to "save the earth".

7 Heidegger's conception of Destruktion or "destructuring", which he applied as a kind of reverse engineering of the history of philosophy hitherto, is the prototype for Derrida's 'deconstruction'.

${ }^{8}$ There is a strong resemblance here too to Raymond Williams's 'escalator' of pastoral nostalgia in The Country and the City.

${ }^{\mathrm{ix}} \mathrm{A}$ chiasmic critique is one that sets up a confrontation between thinkers. John Llewelyn argues that the chiasmus is not "a totalizing synthesis or bland reconciliation. It is a setting out of each from the other ... in which each is in some respect the supplement of the other and each is in turn one step ahead." (viii). I have attempted a chiasmic critique of Heidegger and Seamus Heaney in Garrard 1998.

${ }^{x}$ The nearest to the latter position in ecocriticism would be the early work of both Bate and Lawrence Buell, both of whom propose broadly mimetic theories of environmental representation (Bate, Romantic; Buell, Environmental).

${ }^{x i}$ One of my reviewers observed that the late Wittgenstein whose work I draw on here might be uncongenial to the empiricism I am urging. While some, most notably Richard Rorty, have seen him as an epistemological relativist, I take it (based on the arguments in On Certainty) that Wittgenstein's notion of "language games" does not rule out varying levels and kinds of empirical truth-claim. 